\title{
PERSAINGAN USAHA TIDAK SEHAT DALAM PERDAGANGAN BAHAN PANGAN DIKAITKAN DENGAN UU NO. 5 TAHUN 1999 TENTANG LARANGAN PRAKTIK MONOPOLI DAN PERSAINGAN USAHA TIDAK SEHAT
}

\section{UNFAIR BUSINESS COMPETITION IN COMESTIBLES TRADE RELATED TO LAW NO. 5 OF 1999 CONCERNING PROHIBITION OF MONOPOLY AND PERSAULT PRACTICES}

Hidayat Rumatiga

\author{
Magister Hukum Sekolah Pascasarjana, \\ Universitas Djuanda Bogor. \\ Korespondensi : Hidayat Rumatiga, Telp. - \\ e-mail : hidayat01rumatiga@yahoo.com
}

\begin{abstract}
Jurnal Living Law, Vol. 13, No. 1 , 2021 hlm. 35-45

Abstract : In Indonesia, the formulation of the Anti-Monopoly Law was motivated by an agreement between the International Monetary Fund (IMF) and the Government of the Republic of Indonesia. However, the agreement with the IMF was not the only reason for drafting the law. Even though Indonesia already has an anti-monopoly law, it still practices monopoly in doing business. For example, the monopolistic practices carried out by 12 hen holding companies. sentenced to a total of Rp. 119.8 billion in fines to 11 companies that surpassed the chicken cartel. The verdict was handed down after the Commission Council chaired by Kamser Lumbanradja conducted an examination of Case Number 02 / KPPU-I / 2016 concerning Violation of Article 11 of Law Number 5 Year 1999 concerning cartel agreements at the KPPU hearing, on 13/10/2016 in Jakarta.
\end{abstract}

Keywords : Business Competition; Trade; Comestibles.

\begin{abstract}
Abstrak: Di Indonesia, penyusunan Undang-Undang Anti Monopoli dilatarbelakangi oleh perjanjian antara Dana Moneter Internasional (IMF) dengan Pemerintah Republik Indonesia. Akan tetapi perjanjian dengan IMF tersebut bukan merupakan satu-satunya alasan penyusunan undang-undang tersebut. Meski Indonesia sudah memiliki UU anti monopoli, namun masih melakukan praktek monopoli dalam berbisnis. Sebagai contoh praktek monopoli yang dilakukan oleh 12 Perusahaan induk ayam. menjatuhkan vonis denda dengan total Rp 119,8 Milyar kepada 11 perusahaan yang melampaui kartel ayam. Vonis dijatuhkan setelah Majelis Komisi yang diketuai Kamser Lumbanradja melakukan pemeriksaan terhadap Perkara Nomor 02/KPPU-I/2016 tentang Pelanggaran Pasal 11 UndangUndang Nomor 5 Tahun 1999 tentang perjanjian kartel pada sidang KPPU, pada Tanggal 13 Oktober 2016 di Jakarta.
\end{abstract}

Kata Kunci : Persaingan Usaha; Perdagangan; Bahan Pangan.

\section{PENDAHULUAN}

Dalam kegiatan bisnis, praktek monopoli maupun kartel dapat terjadi, hal ini dapat dipengaruhi oleh sistem ekonomi yang diterapkan,misalnya sistem ekonomi perencanaan. Sistem ekonomi perencanaan ini pernah berlaku di berbagai negara seperti Uni Soviet, dan negera-negara di
Eropa Timur lebih dari satu dasawarsa yang lalu. ${ }^{1}$

Dewasa ini, sudah lebih dari 80 negara di dunia yang telah memiliki undang-

1 Muhamad Rizal, Hukum Persaingan Usaha, Universitas Terbuka, Tangerang Selatan, 2017, Hlm. 3 
undang persaingan dan anti monopoli, ${ }^{2}$ termasuk Indonesia. Jika hukum dibangun di atas dasar struktur sosial dalam masyarakat, bisa dipastikan resistensi masyarakat pada hukum tersebut akan sangat besar dan kuat. ${ }^{3}$

Di Indonesia, penyusunan undangundang anti monopoli dilatarbelakangi oleh perjanjian antara Dana Moneter Internasional (IMF) dengan Pemerintah Republik Indonesia.

Sistem ekonomi yang berlaku di Indonesia ialah ekonomi kerakyatan. Jika konstitusi UUD 1945 menyatakan bahwa perekonomian disusun berdasar atas asas kekeluargaan, harus terwujudnya: 1) Kegiatan unit-unit usaha koperasi pada tingkat mikro dalam suatu ekonomi pasar. 2) Kerja sama ekonomi yang direncanakan pada tingkat ekonomi secara keseluruhan (total economy), dengan unit usaha yang diorganisasikan menurut prinsip birokrasi atau aturan-aturan organisasi. ${ }^{4}$

Meski Indonesia sudah memiliki, namun dalam prakteknya masih melakukan praktek monopoli dalam berbisnis. Sebagai contoh praktek monopoli yang dilakukan oleh 12 Perusahaan induk ayam.

Komisi menjatuhkan vonis denda dengan total $\mathrm{Rp}$ 119,8 Milyar kepada 11 perusahaan yang melampaui kartel ayam. Vonis dijatuhkan setelah Majelis Komisi yang diketuai KamserLumbanradja selesai melakukan pemeriksaan terhadap Perkara Nomor 02/ KPPU-I pada sidang di KPPU, pada 13/10/2016 di Jakarta. ${ }^{5}$

2 Andi Fahmi Lubis, et.al, Hukum Persaingan Usaha Antara Teks Dan Konteks, Komisi Pengawas Persaingan Usaha, Jakarta, 2017, Hlm. 1.

3 Endeh Suhartini \& Danu Suryani, Regulation of Non Smoking Ares In Local Government, De'rechtsstaat. P-ISSN:2442-5303. E-ISSN:25499874. Volume 4 No. 2,September 2018, Hlm. 110.

4 Jochen Ropke, Ekonomi Koperasi Teori Dan Manajemen, Salemba Empat, Jakarta, 2003, Hlm, 25.

5http://m.erabaru.net/2016/10/15/12perusahaan-divonis-bersalah-terkait-kartelayam/diakses 15 Oktober 2016
Kondisi tersebut menunjukkan bahwa pengawasan pemerintah dalam mengatur kegiatan usaha sangat diperlukan, karena tujuan dibuatnya UU No. 5 Tahun 1995 untuk: meningkatkan kesejahteraan rakyat. 6

Pemerintah sebagai lembaga yang berkuasa, memilki wewenang yang diberikan oleh peraturan Perundangundangan untuk mengatur berbagai aspek kehidupan masyarakatnya termasuk persaingan usaha, karena dalam prakteknya, seharusnya konsumen maupun kepada produsen. ${ }^{7}$

Dalam kaitan ini secara garis besar dikenal bentuk-bentuk BUMN dalam system ekonomi sosialis, BUMN dalam system ekonomi kapitalis, dan BUMN dalam system ekonomi campuran. ${ }^{8}$ Dalam negara hukum setiap kebijakan yang dilakukan oleh negara, diatur dalam konstitusi dan UU yang dalam negara itu (legalitas formal). Apabila kekuasaan tidak melaksanakan itu maka dapat diminta pertanggungjawaban dihadapan hukum yang berlaku. ${ }^{9}$

Pada dasarnya, terlaksananya suatu kegiatan bisnis bertujuan untuk memperoleh keuntungan yang seimbang antara produsen, distributor, agen, dan penjual, sehingga dapat menciptakan kesejahteraan bersama. Namun kenyataannya perjanjian afkir dini yang

6 H. T. N. Syamsah \& J. Jopie Gilalo, Upaya Menjamin Pelaksanaan Persaingan Usaha Yang Sehat, Jurnal Hukum De'Rechtsstaat, Volume 1 No. 1. Unida, Bogor, 2015, Hlm. 26.

7 R. Putri Rangkuti et. al, Praktek Larangan Monopoli Dan persaingan Usahan Tidak Pada Bank Pemerintah Dalam Memberikan Subsidi Perumahan, Jurnal Living LAW e-ISSN 25501208 Volume 11 Nomor 2, Oktober 2019 Hlm. 117

8 R. Ali Rido dkk, Hukum Dagang Tentang Surat Berharga, Perseroan Firma, Perseroan Komenditer, Keseimbangan Kekuasaan Dalam PT. dan Penswastaan BUMN, Rema Karya CV, anggota IKAPI, Bandung, 1988, HIm. 363

9 Achmad Jaka Santos Adiwijaya, Menyongsong Pemberlakuan Kewajiban Sertifikat Halal Di Indonesia, Jurnal Ilmiah Living Law, ISSN 20874936 Volume 11 Nomor 1, Januari 2019, HIm. 5. 
dilakukan oleh kedua belas perusahaan indukan ayam menyebabkan harga ayam di pasaran menjadi mahal, membawa kerugian Rp. 224.000.000.000,00 sehingga sulit untuk mewujudkan kesejahteraan bersama, padahal salah satu tujuan untuk mewujudkan kesejahteraan umum, tentunya dilakukan dengan berbagai kegiatan, salah satunya dengan kegiatan bisnis.

Maka, perlu penegakan hukum oleh KPPU sebagai lembaga yang dibentuk oleh pemerintah untuk mengawasi. Atas pelanggaran ini KPPU telah melakukan tindakan pencegahan berdasarkan inisiatif KPPU dengan berdasarkan kewenangan yang diberikan, sehingga pelaku usaha tersebut telah diputus bersalah dengan putusan Nomor:02/KPPU-I/2016. Namun putusan KPPU tersebut kemudian dibatalkan oleh Pengadilan Negeri Jakarta Barat.

Hal ini tentunya menimbulkan persoalan bahwa sebuah lembaga yang menjalankan tugas dan wewenangnya berdasarkan ketentuan UU, kemudian putusannya justru dibatalkan oleh Pengadilan Negeri Jakarta Barat.

\section{METODE PENELITIAN}

Istilah penelitian adalah terjemahan dari bahasa Inggris yang berarti kembali mencari. ${ }^{10}$ Secara harfiah (literal), istilah research kemudian diterjemahkan menjadi upaya untu $\mathrm{k}$ melakukan pencarian kembali. ${ }^{11}$

Metode penelitian adalah prosedur atau cara memperoleh pengetahuan yang benar atau kebenaran melalui langkahlangkah yang sistematis. ${ }^{12}$ Menggunakan pikiran secara seksama dengan cara

10 Bambang Sunggono, Metode Penelitian Hukum, Jakarta, 1997, Hlm. 28

11 Hotma Pardomuan Sibuea \& Heryberthus Sukartono, Metode Penelitian Hukum, Krakatauw Book, Jakarta, 2009, Hlm. 45.

12 Martin Roestamy et al, Metode, Penelitian, Laporan dan Penulisan Karya Ilmiah Hukum pada Fakultas Hukum Universitas Djuanda, Fakultas Hukum Unida, Bogor, 2015, Hlm. 49. mencatat, merumuskan, sampai menyusun laporan. ${ }^{13}$

Pendekatan penelitian ini adalah pendekatan yuridis normatif, asas, atau dogma-dogma. Pendekatan normatif juga dikenal normatif. ${ }^{14}$ pendekatan yuridis normatif digunakan untuk menelaah pembatalan putusan KPPU tentang Nomor 02/ KPPU-I.

\section{PEMBAHASAN}

\section{A. PENGERTIAN PERDAGANGAN DAN PERSAINGAN USAHA TIDAK SEHAT}

Perdagangan merupakan suatu tatanan kegiatan yang terkait dengan transaksi Barang dan/atau Jasa di dalam negeri maupun melampaui batas wilayah negara dengan tujuan pengalihan hak atas Barang dan/atau Jasa untuk memperoleh imbalan atau kompensasi. Perbuatan perdagangan meliputi:

a. Kegiatan jasa komisi; ${ }^{15}$

b. Kapal;

c. Dagangan;

d. Menyewakan dan mencarterkan kapal;

e. Pelayan, pedagang;

f. Semua asuransi.

Ketentuan dalam Pasal 1457 dijanjikan $^{16}$ pengaturan tentang perdagangan diatur dalam hukum dagang perusahaan. ${ }^{17}$

Adapun definisi dari persaingan usaha tidak sehat adalah persaingan antar pelaku usaha dalam menjalankan kegiatan produksi dan atau pemasaran barang atau jasa yang dilakukan dengan cara tidak jujur atau melawan hukum atau menghambat persaingan usaha.

13 Cholod Narbuko dan Abu Achmadi, Metode Penelitian, PT. Bumi Aksara, Jakarta, 2003, 1.

14 Martin Rustamy, Op.cit, Hlm. 50.

15 Abdulkadir Muhammad, Hukum perusahaan Indonesia, cet.4, (Bandung: PT. Citra Aditya Bakti, 2010), Hlm. 13.

16 Gunawan Widjaja, Jual Beli, (Jakarta: PT. Raja Grafindo Persada, 2003), Hlm. 7.

17 Suwardi, Hukum Dagang Suatu Pengantar. (Yogyakarta: Deepublish,2015. ISBN 978602401 1017.Dikutip dari https://id.m.wikipedia.org/wi ki/Hukum_dagang 
Perjanjian yang dilarang dalam praktik perdagangan meliputi:

1. Perjanjian oligopoly

Oligopoly adalah monopoli oleh beberapa pelaku usaha, perusahaan menjual menjual barang yang sama atau produk yang standar. ${ }^{18}$

2. Perjanjian penetapan harga/Cartel

3. Perjanjian pembagian wilayah pemasaran

Ketentuan tentang larangan pembagian wilayah pemasaran termuat dalam Pasal 9 UU No. 5 Tahun 1999.

\section{B. PERAN KPPU DALAM FUNGSI MENGAWASI}

Tugas dan wewenang KPPU diatur dalam Pasal 35 dan Pasal 36 UU 5/99:

Tugas KPPU meliputi:

a. melakukan penilaian terhadap perjanjian yang dapat mengakibatkan terjadinya praktek monopoli dan atau persaingan usaha tidak sehat sebagaimana diatur dalam pasal 4 sampai dengan pasal 16;

b. melakukan penilaian terhadap kegiatan usaha dan atau tindakan pelaku usaha yang dapat mengakibatkan terjadinya praktek monopoli dan atau persaingan usaha tidak sehat sebagaimana diatur dalam pasal 17 sampai dengan pasal 24;

c. melakukan penilaian terhadap ada atau tidaknya penyalahgunaan posisi dominan yang dapat mengakibatkan terjadinya praktek monopoli dan atau persaingan usaha tidak sehat sebagaimana diatur dalam pasal 25 sampai dengan pasal 28;

d. mengambil tindakan sesuai dengan wewenang Komisi sebagaimana diatur dalam pasal 36;

e. memberikan saran dan pertimbangan terhadap kebijakan pemerintah yang berkaitan dengan praktek monopoli dan atau persaingan usaha tidak sehat; f. menyusun pedoman dan atau publikasi yang berkaitan dengan Undang-undang ini;

g. memberikan laporan secara berkala atas hasil kerja Komisi kepada Presiden dan Dewan Perwakilan Rakyat.

Wewenang KPPU meliputi:

a. menerima laporan dari masyarakat dan atau dari pelaku usaha tentang dugaan terjadinya praktek monopoli dan atau persaingan usaha tidak sehat;

b. melakukan penelitian tentang dugaan adanya kegiatan usaha dan atau tindakan pelaku usaha yang dapat mengakibatkan terjadinya praktek monopoli dan atau persaingan usaha tidak sehat;

c. melakukan penyelidikan dan atau pemeriksaan terhadap kasus dugaan praktek monopoli dan atau persaingan usaha tidak sehat yang dilaporkan oleh masyarakat atau oleh pelaku usaha atau yang ditemukan oleh Komisi sebagai hasil dari penelitiannya;

d. menyimpulkan hasil penyelidikan dan atau pemeriksaan tentang ada atau tidak adanya praktek monopoli dan atau persaingan usaha tidak sehat;

e. memanggil pelaku usaha yang diduga telah melakukan pelanggaran terhadap ketentuan undang-undang ini;

f. memanggil dan menghadirkan saksi, saksi ahli dan setiap orang yang dianggap mengetahui pelanggaran terhadap ketentuan Undang-undang ini;

g. meminta bantuan penyidik untuk menghadirkan pelaku usaha, saksi, saksi ahli, atau setiap orang sebagaimana dimaksud huruf e dan huruf $\mathrm{f}$, yang tidak bersedia memenuhi panggilan Komisi;

h. meminta keterangan dari instansi Pemerintah dalam kaitannya dengan penyelidikan dan atau pemeriksaan terhadap pelaku usaha yang melanggar ketentuan Undang-undang ini;

i. mendapatkan, meneliti, dan atau menilai surat, dokumen atau alat bukti

\footnotetext{
18 Muhamad Rizal,Op.cit, Hlm. 43.
} 
lain guna penyelidikan dan atau pemeriksaan;

j. memutuskan dan menetapkan ada atau tidak adanya kerugian di pihak pelaku usaha lain atau masyarakat;

k. memberitahukan putusan Komisi kepada pelaku usaha yang diduga melakukan praktek monopoli dan atau persaingan usaha tidak sehat;

1. menjatuhkan sanksi berupa tindakan administratif kepada pelaku usaha yang melanggar ketentuan Undangundang ini.

\section{BENTUK PERSAINGAN TIDAK SEHAT DALAM PERDAGANGAN BAHAN PANGAN}

Penulis melihat bahwa dalam
perdagangan bahan pangan yaitu
perdagangan indukan ayam atau Day Old
Cickhen (DOC), ada berbagai macam
pelanggaran usaha, diantaranya:

1. Adanya perjanjian yang dilarang/kartel ayam

Perjanjian (kartel) untuk melakukan afkir dini atau pemusnahan masal indukan ayam sebelum waktunya melibatkan 12 (dua belas) perusahaan ayam, yaitu: ExpravetNasuba, dll. ${ }^{19}$

Perjanjian ini dilakukan pada 14 September 2015. Pada bulan September para pelaku usaha sepakat untuk melakukan afkir dini.

2. Pemusnahan objek perdagangan berupa dua juta anak ayam secara masal

Pada 14 September 2015 para pelaku usaha melakukan pemusanahan indukan ayam dalam jumlah yang besar yaitu sebesar dua juta Day of Cikhen (DOC) atau anak ayam. Komisi menilai bahwa pemusnahan indukan ayam ini terlalu besar dan menimbulkan kerugian yang besar, dengan asumsi satu ekor ayam dewasa menghasilkan sekitar 32 DOC, sehingga

19 http://m.erabaru.net/2016/10/15/12perusahaan-divonis-bersalah-terkait-kartelayam/, diakses 15/10/2016 dengan membunuh dua juta anak ayam sama dengan membunuh enam puluh empat juta DOC yang siap diternakkan. Adapun alasan pemusnahan induk ayam ini ialah karena stok induk ayam melebihi permintaan dalam pasaran. Pelaku usaha berdalih bahwa pemusnahan induk ayam ini didasarkan pada intruksi Instruksi Dirjen Peternakan \& Kesehatan Hewan Nomor:15043/FK.010/F/10/2015.

3. Sebelum waktunya (afkir dini)

Berdasarkan asumsi KPPU satu ekor ayam dewasa menghasilkan sekitar 32 anak ayam atau day of cickhen (DOC), sehingga dengan membunuh dua juta anak ayam sama dengan membunuh enam puluh empat juta DOC yang siap diternakkan.

4. Penguasaan pasar $85 \%$

Kedua belas perusahaan diketahui menguasai pasar 85\% (delapan puluh lima persen $)^{20}$ sehingga kebijakan yang dilakukan pasti berpengaruh pada produksi, pemasaran dan pengaturan harga ayam.

Akibat yang ditimbulkan dari afkir dini atau pemusnahan masal ini diantaranya:

1. Supply daging ayam menjadi langkah

2. Harga Day Old Cikhen (DOC) atau anak ayam menjadi mahal di pasar

3. Enam puluh empat juta ekor Day Old Cikhen (DOC) atau anak ayam tidak masuk ke pasaran

4. Kerugian Rp.224.000.000.000,00

Akibat yang timbul dari pelaksaan afkir dini melalui perjanjian kartel ini dampaknya sangat besar terhadap perekonomian Negara, sehingga perlu adanya penindakan hukum melalui lembaga yang bertugas melakukan pengawasan yaitu KPPU.

Oleh karena perjanjian kartel merupakan pelanggaran dalam persaingan usaha maka perlu diberantas demi terwujudnya ekonomi kerakyatan yang menjadi asas dalam kegiatan ekonomi Indonesia, sebagaimana diamanantkan

20 CNN Indonesia, Awas Kartel Ayam, (Berita) 2016 
dalam UUD NRI Tahun 1945, yang bertujuan untuk mewujudkan kesejahteraan masyarakat. Apalagi kedua belas perusahaan ayam yang divonis bersalah oleh KPPU diketahui menguasai $85 \%$ populasi stok indukan ayam, tentunya kegiatan ekonominya sangat berpengaruh dalam ketersediaan kebutuhan bahan pangan di Indonesia.

Sebagai Negara hukum, sebagaimana "Indonesia adalah Negara hukum", maka pelaksanaan kegiatan ekonomi melalui bisnis ayam atau kebijakan yang yang dilakukan oleh pemerintah maupun instansi lainnya di dalam wilayah Negara Republik Indonesia harus berdasarkan ketentuan perundang-undangan yang berlaku dengan memperhatikan hirarki peraturan perundang-undangan, asas-asas, dan prinsip-prinsip yang melandasi suatu kegiatan ekonomi, serta teori-teori yang berhubungan dengan hukum.

Adapun yang melandasi kegiatan ekonomi di Indonesia ialah asas demokrasi ekonomi. Kepentingan umum ialah kepentingan Negara dan masyarakat. Selain itu penegakan yang dilakukan oleh KPPU dalam mencegah perjanjian kartel tersebut untuk mewujudkan tujuan terbentuknya termuat dalam Pasal 3.

Untuk mewujudkan tujuan tersebut KPPU melaksanakan tugas dan fungsinya dengan pendekatan prinsip per se illegal, yaitu penindakan karena adanya pengafkiran dini indukan ayam, sedangkan untuk membuktikannya KPPU menggunakan pendekatan prinsip rule of reason yaitu penindakan atas perjanjian yang dilakukan oleh kedua belas perusahaan indukan ayam karena menilai pernjanjian tersebut menyebabkan Supply daging ayam menjadi langkah, Harga Day Old Cikhen (DOC) atau anak ayam menjadi mahal di pasar, Enam puluh empat juta ekor Day Old Cikhen (DOC) atau anak ayam tidak masuk ke pasaran, Kerugian Rp.224.000.000.000,00.

Pelaksanaan tugas dan fungsi KPPU atas pelanggaran, bila dikaitkan dengan teori hukum pembangunan, maka sangatlah relevan, dimana dalam teori hukum pembangunan yang dikemukakan oleh Mochtar Kusumaatmadja, ialah unsur hukum terdiri dari kaedah, asas, lembaga dan proses, yang merupakan sarana pembaharuan dan sarana pembangunan guna menciptakan adanya keteraturan dan atau ketertiban.

Sebagai kaedah, hukum berfungsi sebagai pengatur atau arah pembangunan atau pembaharuan.

Sebagai asas hukum memberikan landasan dalam pembentukan system hukum untuk mencapai tujuan Negara.

Sebagai sarana pembangunan, hukum juga berfungsi sebagai sarana mewujudkan kesejahteraan rakyat. ${ }^{21}$

Sehingga dengan menerapkan perintah, dapat tercapai tujuan Negara dalam mewujudkan kesejahteraan rakyat.

Prilaku menyimpang dalam dunia usaha merupakan satu dari persoalan hukum yang sering terjadi di era globalisasi ini, karena adanya perubahan perilaku manusia, maka diperlukan suatu konsepsi hukum yang relevan dengan penyimpangan tersebut. Berangkat dari perubahan perilaku masyarakat yang demikian cepat karena kuatnya pengaruh perubahan lingkungan dimana dia tinggal yang diakibatkan oleh pesatnya pembangunan, maka menurut Prof. Mochtar Kusumaatmadja hal yang sangat mendasar adalah membuat suatu peraturan hukum yang up to date. Dengan kata lain, hukum tridak boleh ketinggalan dengan proses perkembangan yang terjadi di dalam masyarakat. Pembangunan yang berkesinambungan menghendaki adanya konsep hukum yang mampu mendorong dan mengarahkan pembangunan sebagai cerminan dari tujun hukum modern. ${ }^{22}$ Sehingga dapat mengimbangi pesatnya kemajuan zaman. Artinya dalam

21 Martin Roestamy et al, Lop. Cit, Hlm. 147.

22 Mochtar Kusumaatmadja, Konsep-Konsep Hukum dalam Pembangunan, Edisi I, (bandung: 2020), Hlm. v. 
masyarakat (living law). Hal ini jurisprudence. ${ }^{23}$

Pandangan ahli tersebut relevan dengan masalah yang dikaji dalam penulisan ini, yaitu penegakan hukum atas pelanggaran yakni 12 perusahaan indukan ayam, menunjukkan bahwa hukum masih hidup dalam masyarakat dan terus berkembang sehingga dapat menjawab masalah hukum yang terjadi di Indonesia. Artinya penegakan hukum sesuai ketentuan masih dapat menyelesaikan jenis pelanggaran usaha, yaitu perjanjian kartel.

Pelaksanaan tugas dan fungsi KPPU, melalui proses hukum yang benar sesuai ketentuan perundang-undangan yang berlaku, sehingga melahirkan putusan atas suatu pelanggaran, maka KPPU mewujudkan kepastian hukum khusus di bidang persaingan usaha, karena hukum harus memberikan kepastian dalam suatu kegiatan, sebagaimana pendapat Sudikno Mertukusumo menurutnya ditaati. ${ }^{24}$ Penegakan hukum oleh KPPU sebagai langkah preventif atas pelanggaran UU persaingan usaha, yang pada akhirnya memaksa para pelaku usaha untuk menaati hukum dalam hal ini.

Dengan demikian, perjanjian yang dilakukan 12 (dua belas) perusahaan indukan ayam merupakan perjanjian kartel yang bertentangan. Karena adanya perjanjian usaha, pemusnahan objek perdagangan, dilakukan sebelum waktunya.

\section{BENTUK PENEGAKAN HUKUM DALAM PELANGGARAN PERSAINGAN USAHA PRAKTEK}

\section{Kasus Posisi}

$\begin{array}{ll}\text { Inisiator } & : \text { KPPU } \\ \text { Lembaga Peradilan } & : \text { Majelis Komisi } \\ \text { Jenis Perkara } & : \text { Perjanjian kartel } \\ \text { Nomor } & : 02 / \text { KPPU-I/2016 }\end{array}$

23 Edy Santoso, Pengaruh Era Globalisasi Terhadap Hukum Bisnis di Indonesia, (Jakarta Timur: Kencana,2018), Hlm. 200.

24 Sudikmo Mertokusumo, lop.cit, Hlm. 160. a. Pelaku usaha melakukan perjanjian pada 14 September 2015.

b. Pengafkiran dini indukan ayam berjumlah dua juta ekor.

\section{Putusan KPPU}

a. Membatalkan perjanjian pengafkiran dini indukan ayam pada 14 September 2015.

b. Memutuskan 12 (dua belas) perusahaan melanggar.

c. Menjatuhkan sanksi denda Rp.120.000.000.000, 00 (seratus dua puluh milyar)

\section{Pertimbangan Hukum}

a. Pertimbangan hukum atas putusan KPPU Nomor:02/KPPU-I/2016 sesuai.

b. Pertimbangan hukum atas penjatuhan sanksi denda bagi pelaku usaha dalam melakukan afkir dini sesuai ketentuan tersebut tercantum.

\section{Sanksi KPPU}

Putusan KPPU Nomor:02/KPPUI/2016 mengandung sanksi berupa:

a. Pembatalan perjanjian afkir dini indukan ayam oleh kedua belas perusahaan;

b. Penjatuhan denda kepada sebelas perusahaan sebesar Rp.120.000.000.000, 00 (seratus dua puluh milyar).

\section{Kekuatan hukum putusan KPPU}

Disebutkan "Pelaku usaha tersebut." Sehingga putusan KPPU tidak berkekuatan hukum tetap kecuali tidak ada pengajuan keberatan dalam waktu 14 hari

\section{Pembatalan Putusan KPPU} Nomor:02/KPPU-I/2016

Pengadilan Negeri Jakarta Barat menerima permohonan keberatan 12 perusahaan dan membatalkan putusan KPPU Nomor:02/KPPU-I/2016 dengan putusan Nomor:

1/Pdt.Sus.KPPU/2017/PN.Jkt.Brt. selanjutnya atas pembatalan tersebut KPPU mengajukan permohonan kasasi ke Mahkamah Agung (MA), namun 
yang diajukan oleh KPPU ditolak dengan putusan Nomor:444k/Pdt.SusKPPU/2018.

\section{Implementasi dikaitkan dengan pembatalan putusan KPPU Nomor:02/KPPU-I/2016}

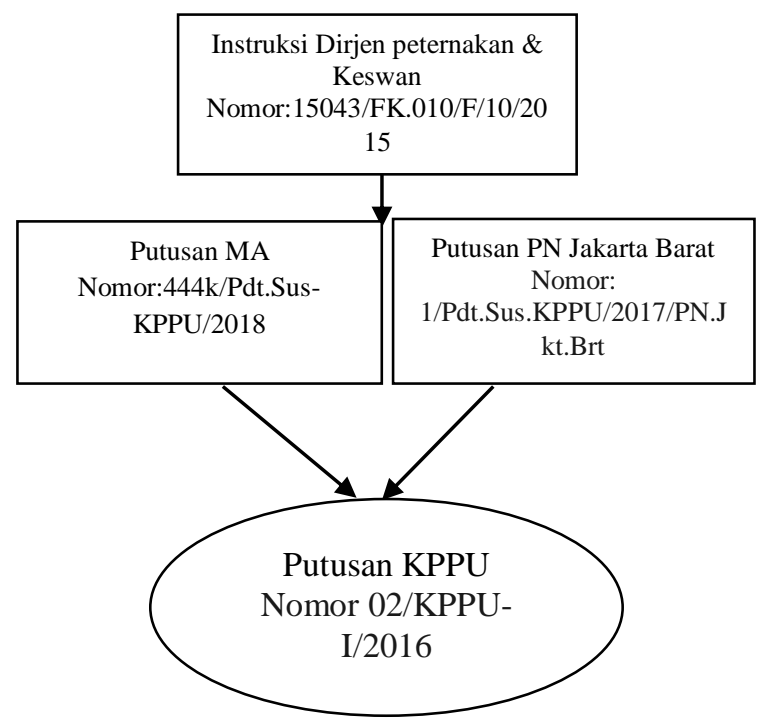

Dalam skema tersebut dapat dipahami bahwa intsruksi Dirjen Kementerian Pertanian Republik Indonesia seakan lebih lebih tinggi, karena putusan pengadilan Negeri Jakarta Barat dan penolakan kasasi oleh Mahakamh Agung didasarkan pada instruksi tersebut, padahal dalam hirarki peraturan perundang-undangan instruksi dirjen tidak disebutkan.

Hirarki peraturan perundangundangan yang termuat UU No. 15 Tahun 2019 ialah sebagai berikut: Ayat (1): 1) UUD 1945; 2) TAP MPR; 3) Undang-Undang; 4) UndangUndang/Peraturan Pemerintah Pengganti Undang-Undang; 5) Peraturan Pemerintah; 6) Peraturan Presiden; 7) Peraturan Daerah Provinsi; dan 8) Peraturan Daerah Kabupaten/Kota.

Dari ketentuan tersebut, maka intsruksi Dirjen Kementerian Pertanian Republik Indonesia tidak bisa dijadikan alasan untuk membatalkan yang pembentukan dan kewenangannya diberikan oleh Undang-undang, yaitu UU No. 5.
Selain tidak sejalan dengan ketentuan Pasal 7 ayat (2), alasan pembatalan putusan KPPU juga tidak sesuai dengan asas (peraturan perundang-undangan yang lebih tinggi mengesampingkan peraturan yang rendah). sehingga peraturan lembaga lain yang kekuatan hukumnya termuat dalam peraturan di bawah UU tidak dapat mengesampingkan kewenangan KPPU, yaitu intsruksi Dirjen Kementerian Pertanian Republik Indonesia.

Begitu juga dengan asas (peraturan perundang-undangan yang khusus mengesampingkan peraturan yang umum). Kekhususan KPPU dalam melaksanakan tugas pengawasan di bidang persaingan usaha tidak bisa disampingkan oleh instruksi Dirjen Kementerian Pertanian Republik Indonesia. Meperkuat status KPPU sebagai lembaga independen yang khusus mengawasi persaingan usaha di Indonesia. Kekhususan lembaga ini dibentuk dengan tujuan sebagaimana termuat dalam Pasal 3.

Rumusan ini mengandung makna secara implisit bahwa KPPU dibentuk untuk menjalankan amanah konstitusi yaitu UUD NRI Tahun 1945.

Adapun alasan instruksi Dirjen Kementerian Pertanian Republik Indonesia bahwa perintah pemusanahan dengan mengeluarkan instruksi

Nomor:15043/FK.010/F/10/2015

karena kelebihan stok induk ayam akibat impor tahun 2013 tidak dapat dijadikan alasan untuk mengesampingkan pelaksanaan tugas dan wewenang sebuah lembagA independen, yaitu KPPU.

Dari pembahasan di atas, maka penulis menemukan dua hal yaitu 1) pembatalan putusan KPPU oleh Pengadilan Negeri Jakarta Barat dan penolakan kasasi oleh Mahkamah Agung mengabaikan ketentuan UU No. 15 Tahun 2019 2) pembatalan putusan KPPU oleh Pengadilan Negeri Jakarta Barat dan penolakan kasasi oleh 
Mahkamah Agung berdasarkan instruksi Dirjen Peternakan dan Kesehatan Hewan Kementerian Pertanian Republik Indonesia Nomor: 15043/FK.010/F/10/2015 tidak dapat mengesampingkan dalam mengawasi.

\section{KESIMPULAN}

1. Bentuk dalam perdagangan bahan pangan (indukan ayam) yang dilakukan oleh 12 (dua belas) perusahaan indukan ayam merupakan perjanjian kartel, karena pelaku usaha melakukannya, selain itu perjanjian kedua belas perusahaan tersebut dapat digolongkan perjanjian Penetapan Harga, karena dengan melakukan pemusanahan indukan ayam akan melahirkan kesepakatan atas harga atas ayam yang ingin dipasarkan kembali. Perjanjian tersebut bertentangan dengan Pasal 5.

2. Putusan KPPU Nomor:02/KPPUI/2016 sudah sesuai dengan ketentuan, karena dilakukan berdasarkan tugas dan fungsi, serta wewenang yang ada pada KPPU. Sedangkan pembatalan putusan KPPU oleh Pengadilan Negeri Jakarta Barat dan penolakan kasasi oleh Mahkamah Agung mengabaikan ketentuan UU No. 15 Tahun 2019, Sehingga Pembatalan putusan KPPU oleh Pengadilan Negeri Jakarta Barat dan penolakan kasasi oleh Mahkamah Agung berdasarkan instruksi Dirjen Peternakan \& Kesehatan Hewan Keme nterian Pertanian Republik Indonesia Nomor:15043/FK.010/F/10/2015 tidak dapat dijadikan alasan untuk mengesampingkan tugas dan fungsi, serta wewenang KPPU dalam mengawasi.

\section{SARAN}

1. Pengawasan terhadap kegiatan bisnis harus terus dilakukan oleh KPPU sebagai pelaksanaan tugas dan fungsi yang diberikan.

2. Pemerintah harus memberi kewenangan kepada KPPU untuk mengadili perkara tingkat pertama sampai terakhir sehingga putusan KPPU bersifat final dan berkuatan hukum tetap. Kebijakan pengaturan dalam kegiatan usaha harus dikordinasikan dengan KPPU untuk mencapai suatu keputusan bersama.

\section{DAFTAR PUSTAKA}

Andi Fahmi Lubis, et. al, Hukum Persaingan Usaha Antara Teks Dan Konteks, (Komisi Pengawas Persaingan Usaha, Jakarta, 2017).

Achmad Jaka Santos Adiwijaya, Menyongsong Pemberlakuan Kewajiban Sertifikat Halal Di Indonesia, Jurnal Hukum Living Law, ISSN 2087-4936 Volume 11 Nomor 1, Januari 2019)

Arie Siswanto, Hukum Persaingan Usaha, Cetakan Pertama (Jakarta: Ghalia Indonesia, 2002).

Abdulkadir Muhammad, Hukum perusahaan Indonesia, cet.4, (Bandung: PT. Citra Aditya Bakti, 2010).

Bambang Sunggono, Metode Penelitian Hukum, (Jakarta, 1997)

CNN Indonesia, Awas Kartel Ayam, (Berita) 2016 
Edy Santoso, Pengaruh Era Globalisasi Terhadap Hukum Bisnis di Indonesia, (Jakarta Timur: Kencana,2018).

Endeh Suhartini \& Danu Suryani, Regulation Of Non Smoking Ares In Local Government, De'rechtsstaat. P-ISSN:2442-5303. E-ISSN:2549-9874. Volume 4 No. 2,September 2018).

Cholod Narbuko dan Abu Achmadi, Metode Penelitian, PT. Bumi Aksara, Jakarta, 2003, 1.

Gunawan Widjaja, Jual Beli, (Jakarta: PT. Raja Grafindo Persada, 2003).

Halim, A. Ridwan, Hukum Dagang Dalam Tanya Jawab. (Jakarta: Ghalia Indonesia, 1985)

Hotma Pardomuan Sibuea \& Heryberthus Sukartono, Metode Penelitian Hukum, (Krakatauw Book, Jakarta, 2009),

H.M.N. Purwosutjipto, Pengertian Pokok Hukum Dagang Indonesia, (Djakarta: Djambatan, 2007).

H. T. N. Syamsah \& J. Jopie Gilalo, Upaya Menjamin Pelaksanaan Persaingan Usaha Yang Sehat, Jurnal Hukum De'Rechtsstaat, Volume 1 No. 1. Unida, Bogor, 2015.

Jochen Ropke, Ekonomi Koperasi Teori Dan Manajemen, (Salemba Empat, Jakarta, 2003).

Knud Hansen et al. Undang-Undang Larangan Praktik Monopoli dan Persaingan Usaha Tidak Sehat, (Katalis Publishing-Media Services, 2002).

Muhamad Rizal, Hukum Persaingan Usaha, (Universitas Terbuka, Tangerang Selatan, 2017) Mochtar Kusumaatmadja, Konsep-Konsep Hukum dalam Pembangunan, Edisi I, (bandung: 2020).

\section{Merriam Webster, Dictionary}

R. Putri Rangkuti et. al, Praktek Larangan Monopoli Dan persaingan Usahan Tidak Pada Bank Pemerintah Dalam Memberikan Subsidi Perumahan, Jurnal Living LAW e-ISSN 2550-1208 Volume 11 Nomor 2, Oktober 2019

R. Shyam Khemani, Onjectif of Competition Policy, Competition Law Policy Commottee of the OECD, OECD Document, N.d, dalam Ari Siswanto, Hukum Persaingan Usaha, (Jakarta: Ghalia Indonesia, 2004).

R. Ali Rido dkk, Hukum Dagang Tentang Surat Berharga, Perseroan Firma, Perseroan Komenditer, Keseimbangan Kekuasaan Dalam PT. dan Penswastaan BUMN, Rema Karya CV, anggota IKAPI, Bandung, 1988, Hlm. 363

Roestamy Martin et al, Metode, Penelitian, Laporan dan Penulisan Karya Ilmiah Hukum pada Fakultas Hukum Universitas Djuanda, (Fakultas Hukum Unida, Bogor, 2015).

Suwardi, Hukum Dagang Suatu Pengantar. (Yogyakarta: Deepublish,2015. . ISBN 9786024011017.Dikutip dari https://id.m.wiki pedia.org/wiki/Hukum_dagang 
William J. Baumol dan Alan S. Blinder, Economics, Principles and Policy, Third edition, (Harcourt Brace Jovanovich Publisher Orlando, Florida, 1985).

https://id.m.wikipedia.org/wiki/Hukum_dagang

http://m.erabaru.net/2016/10/15/12-perusahaan-divonis-bersalah-terkait-kartel-ayam/, diakses 15/10/2016

http://m.erabaru.net/2016/10/15/12-perusahaan-divonis-bersalah-terkait-kartel-ayam/ diakses 15 Oktober 2016 